\title{
Reiki as nursing care to people in mental suffering: an integrative review
}

\author{
Reiki como cuidado de enfermagem às pessoas em sofrimento psíquico: revisão integrativa \\ Reiki como cuidado de enfermería a las personas en sufrimiento psíquico: revisión integrativa
}

Cândida Maria Rodrigues dos Santos ' ORCID: 0000-0003-4196-7413

Marília de Oliveira Crispim ORCID: 0000-0002-3931-0722

Thassia Thame de Moura Silva' ORCID: 0000-0003-1067-7421

Rute Costa Régis de Souza' ORCID: 0000-0002-2670-2620

Cecília Maria Farias de Queiroz Frazão' ORCID: 0000-0001-6403-7505 Iracema da Silva Frazão' ORCID: 0000-0002-4690-3753

'Universidade Federal de Pernambuco. Recife, Pernambuco, Brazil.

How to cite this article Santos CMR, Crispim MO, Silva TTM, Souza RCR, Frazão CMFQ, Frazão IS. Reiki as nursing care to people in mental suffering: an integrative review. Rev Bras Enferm. 2021;74(Suppl 3):e20200458 doi:http://dx.doi.org/10.1590/0034-7167-2020-0458

\section{Corresponding author:}

Cândida Maria Rodrigues dos Santos

E-mail: candidaenf@yahoo.com.br

EDITOR IN CHIEF: Antonio José de Almeida Filho ASSOCIATE EDITOR: Priscilla Broca

Submission: $07-27-2020 \quad$ Approval: $10-18-2020$

\section{ABSTRACT}

Objective: To analyze the scientific evidences of the use of Reiki as a care strategy to people in mental suffering. Methods: Integrative review in the databases PubMed, Scielo, Web of Science, and BVS. The study included articles in English, Portuguese, and Spanish, with no time restriction, which answer to the guiding question that was created in accordance to the PICo strategy: "What are the scientific evidences on the use of Reiki as a care strategy to people in mental suffering?" Gray literature was not considered. Results: Ten articles made up the final sample. The use of the Reiki therapy had benefits as a strategy to care for stress, anxiety, depressive symptoms, pain relief, and quality of life improvements, whether the therapy was used isolated or to complement other treatments. Conclusion: The development of the competence of nurses and other health professionals in the use of Reiki can contribute to improve the quality standards of care.

Descriptors: Mental Suffering; Holistic Therapy; Therapeutic Touch; Nursing Care; Review.

\section{RESUMO}

Objetivo: Analisar as evidências científicas do uso do Reiki como estratégia de cuidado às pessoas em sofrimento psíquico. Métodos: Revisão integrativa nas bases de dados PubMed, Scielo, Web of Science e BVS. Foram incluídos artigos em inglês, português e espanhol, sem restrição quanto ao ano de publicação, que respondessem à pergunta condutora construída com uso da estratégia PICo: "Quais as evidências científicas sobre o uso do Reiki como estratégia de cuidado à pessoa em sofrimento psíquico?" A literatura cinzenta foi excluída. Resultados: Dez artigos compuseram a amostra final. O uso da terapia Reiki apresentou benefícios como estratégia de cuidado no estresse, ansiedade, sintomas depressivos, alívio da dor e melhora na qualidade de vida, seja a terapia utilizada de forma isolada ou complementar a outro tratamento. Conclusão: $\mathrm{O}$ desenvolvimento de competências dos enfermeiros e demais profissionais da saúde utilizando o Reiki contribui para a melhoria dos padrões de qualidade dos cuidados.

Descritores: Sofrimento Psíquico; Terapias Holísticas; Toque Terapêutico; Cuidados de Enfermagem; Revisão.

\section{RESUMEN}

Objetivo: Analizar evidencias científicas del uso del Reiki como estrategia de cuidado a las personas en sufrimiento psíquico. Métodos: Revisión integrativa en las bases de datos PubMed, Scielo, Web of Science y BVS. Incluidos artículos en inglés, portugués y español, sin restricción cuanto al año de publicación, que respondieran a la interrogación con uso de la estrategia PICo:" ¿Cuáles las evidencias científicas sobre el uso del Reiki como estrategia de cuidado a la persona en sufrimiento psíquico?". Resultados: Diez artículos compusieron la muestra final. El uso del Reiki presentó beneficios como estrategia de cuidado en el estrés, ansiedad, síntomas depresivos, alivio del dolor y mejora en la calidad de vida, sea la terapia utilizada de forma aislada o complementar a otro tratamiento. Conclusión: El desarrollo de competencias de los enfermeros y demás profesionales de salud utilizando el Reiki contribuye para la mejoría de los estándares de calidad de los cuidados.

Descriptores: Sufrimiento Psíquico; Terapias Holísticas; Toque Terapéutico; Cuidados de Enfermería; Revisión. 


\section{INTRODUCTION}

Mental disorders affect at least 450 million people around the world, and is responsible, in the Americas, for one third of the total number of psychic disabilities that prevent work ${ }^{(1-2)}$.

Mental disorders are social phenomena, seen by many according to the culture of each era. However, despite advances, it is still not possible to reach a consensual definition of mental health problems, which, depending on the theoretical references adopted, can also me called mental disorders, mental suffering, and mental suffering ${ }^{(3)}$. For this integrative review, we chose to use the term "pessoas em sofrimento psíquico" (people in mental suffering), since these terms are in line to the postulates of the mental health policy established in Brazil( ${ }^{(4)}$.

Mental suffering is a health problem with a high index of morbidity in contemporary society, and is considered to be an important public health issue ${ }^{(5)}$.

In Brazil, studies found a prevalence varying from $20 \%$ to $56 \%$ of adults in mental suffering, including mood disorders, somatic symptom disorder, alcohol abuse, and anxiety ${ }^{(6)}$. The latter, in particular, is considered to be epidemic, with a prevalence of 9.3\%; this number means that the country is the first, considering South America, in psychic disabilities caused by this disorder ${ }^{(2)}$.

People in mental suffering present high levels of functional disability, with impairment in daily activities, work, and social relations ${ }^{(7)}$. The disability associated to psychic sufferings leads to social and economic impairments, reverberating in the way in which health care services are organized ${ }^{(8)}$. Despite the fact that many countries have changed their mental health policies, there is more demand than supply of services, and there is a high percentage of adults and children, especially in native/indigenous populations, with severe mental disorders that go untreated ${ }^{(2)}$.

Psychic suffering may be associated to clinical comorbidities such as metabolic, cardiovascular, or endocrine disorders, cancer and HIV/AIDS ${ }^{(9-11)}$, leading to repercussions in health care, family, health managers, and user rehabilitation ${ }^{(12)}$.

The traditional model of treatment to these health problems is focused on the prescription of psychiatric drugs and psychotherapies $^{(13)}$. However, it is necessary to search for other health care options that are effective for people in mental suffering, minimizing the collateral effects and attending to the needs of this group of clients.

An alternative to the traditional model focused on the use of psychiatric drugs are Complementary and Integrative Practices (PICs), implemented in Brazil by the National Policy of Complementary and Integrative Practices (PNPIC) ${ }^{(14)}$. The PICs are resources that have been increasingly used, since they promote humane care, focused on the client, in addition to aiding in the process of health recovery, respecting and giving support to the preexisting therapeutic care ${ }^{(15)}$.

Among the PICs offered in the scope of health care, we can highlight Reiki as a therapeutic practice that uses the laying on of hands to channel vital energy, seeking to promote the energetic balance that is necessary to physical and mental wellbeing ${ }^{(16)}$.

Some researches point out that the Reiki therapy can contribute in the care to people in mental suffering, diminishing the levels of anxiety and depression ${ }^{(17)}$, relaxation and stress management ${ }^{(18)}$, as well as reducing burnout ${ }^{(19)}$. Its use brings new possibilities to care in a simple, safe, and non-invasive manner, since it is considered to be a low-risk intervention that is used among the many professionals who work in the hospital sectors and in Primary Care ${ }^{(20-21)}$.

Among the professions in the field of health, nursing is defined as the profession of direct, effective, and holistic care. As a result, the therapeutic touch offers the possibility of changing day to day care even more, that is, of transforming the experience of the patient through an embracing, pleasant, and unique experience, developing a therapeutic relationship through the creation of bonds and confidence ${ }^{(22)}$.

Thus, Reiki presents itself to nurses as a specialized practice of care, regulated in Brazil according to a Decree from the National Council of Nursing (COFEN) 581/2018 $8^{(23)}$.

Previous studies $^{(24-25)}$ have reviewed literature in order to verify how Reiki contributed in the many settings of care. Nevertheless, the sources researched still have few publications that studied this practice as a therapy in the care of people in mental suffering. Finding more about the use of this therapy to this end, nurses will be able to give it scientific support, using it in their daily practices.

\section{OBJECTIVE}

To analyze scientific evidences of the use of Reiki as a care strategy to people in mental suffering.

\section{METHODS}

This is an integrative review following the model proposed by Whittemore and Knafl: 1) identification of the team or question of the integrative review; 2) sampling or literature search;3) evaluation and categorization of the studies included in the integrative review; 4) data analysis; and 5) summary of the knowledge shown in the articles analyzed, or presentation of the integrative review ${ }^{(26)}$.

To elaborate the research question, an adaptation of the PICO strategy (Patient, Intervention, Comparison, and Outcomes) was used, since not all elements of the strategy apply to the choice of the question of this review ${ }^{(27)}$. In this integrative review, the third and fourth elements were substituted by "context", and then the strategy PICo (Problem/Population, Interest and Context) was employed.

As a result, the guiding question of the review was elaborated considering: (P) - person in mental suffering; (I) - use of Reiki; and (Co) - use of Reiki as a strategy of care. Finally, the following guiding question was defined:"What are the scientific evidences about the use of Reiki as a health care strategy to the person in mental suffering?".

A literature search was carried out through the databases PubMed, SciELO, Web of Science, and BVS, in October 2019, regardless of year of publication and using the language filters for Portuguese, English, and Spanish. Only articles whose full text was available were considered. The research used indexed descriptors, namely "Mental Disorders", "Holistic Therapies", and "Therapeutic Touch", with the aid of the boolean operators AND and OR. The same search strategy was used in all databases "Mental Disorders"AND ("Therapeutic Touch"OR"Holistic Therapies").

Inclusion criteria included original articles, in Portuguese, English, and Spanish, which highlighted Reiki as a health care strategy for people undergoing psychic suffering, according to the guiding question of the research. The criteria of exclusion adopted included: theses, dissertations, books or book chapters, editorials, newspaper articles, integrative or systematic reviews, 
case studies, experience reports of articles describing experiments that did not involve human beings. Other details are in Figure 1.

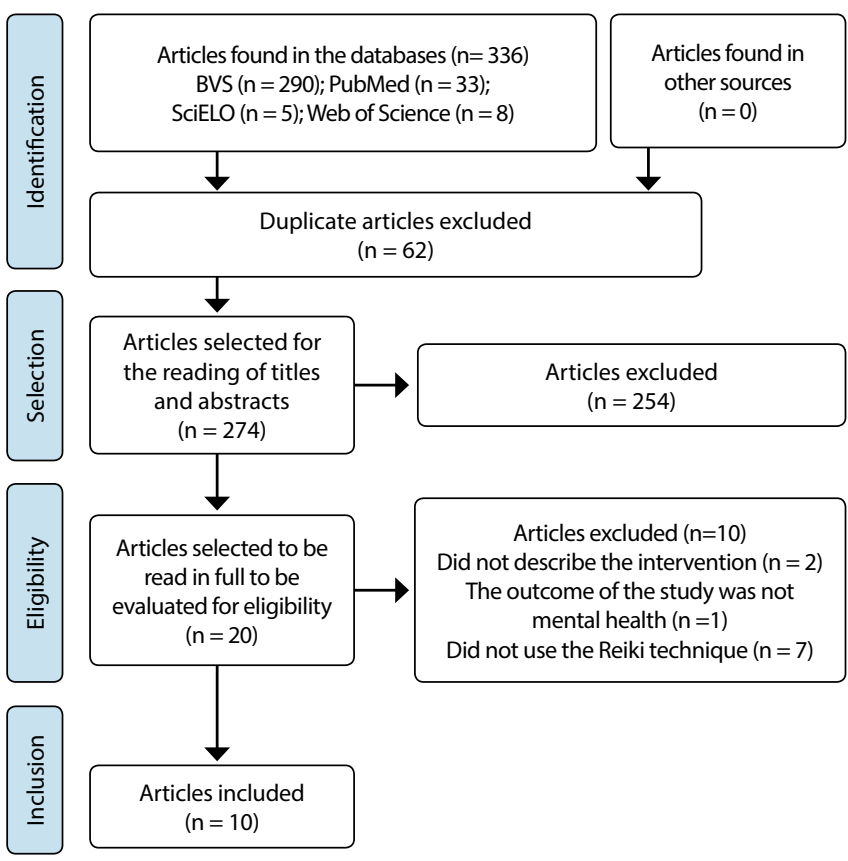

Figure 1 - Flowchart of the process of identification, selection, and inclusion of the studies, elaborated according to Preferred Reporting Items for Systematic Reviews and Meta-Analyses - PRISMA recommendations ${ }^{(28)}$

For the third stage, study categorization, a validated instrument ${ }^{(29)}$ was used to verify the following variables: year, authors, database and country in which the research was carried out, level of evidence, objective, outcomes, and main conclusion of the studies.

The evaluation of the studies included in the review was the fourth stage of the study and was carried out according to the level of evidence proposed by Fineout-Overholt et al. ${ }^{(30)}$, which establishes six categories: Level I - Evidences from systematic reviews or meta-analyses of relevant clinical essays; Level II - Evidences derived from at least one control and well-designed randomized clinical trial, moderate evidence; Level III - Well designed nonrandomized clinical trials; Level IV - Well designed cohort studies and case studies; Level V - Systematic review of descriptive and qualitative studies, weak evidence; Level VI - Evidences derived from a single descriptive or qualitative study; Level VII - Opinion of authorities or report from specialist committees.

In the fifth stage, regarding the interpretation of results, the following were extracted from the articles: target-population, instrument used to evaluate mental suffering, type of mental suffering, protocol for the use of Reiki, and therapies used in association with Reiki as a research outcome.

\section{RESULTS}

The final sample was made up by ten studies, published from 2004 to 2017 (Chart 1). The articles selected came from four countries: the United States (6), the United Kingdom (2), Brazil (1), and Italy (1).

Regarding the level of evidence and the type of study, quasiexperimental studies (Level III) and clinical trials (Level II) were the most frequent, with three ${ }^{(31-33)}$ and seven studies ${ }^{(34-40)}$, respectively.

It stands out that all articles presented, as their target population, adults with some degree of psychic suffering. Although the author of an article ${ }^{(37)}$ selected a sample with "healthy" participants, after the scale was applied, most of them were found to have an anxiety score.

Regarding the instruments to measure the effects of the Reiki technique in the participants of the study, the most common ones were: Spielberg Anxiety Inventory ${ }^{(33,35)}$, Visual Analog Scales (VAS) for Pain and Anxiety ${ }^{(31,35)}$, Perceived Stress Scale (PSS) ${ }^{(32,40)}$, Depression, Anxiety, and Stress Scale (DASS), Pittsburgh Quality of Sleep Index (PSQI), Illness Symptoms Questionnaire, Activation Deactivation Adjective Check List (AD-ACL), Reiki-Blinding and Expectation Questionnaire and Illness Symptoms Questionnaire (ISQ) ${ }^{(37-38)}$.

Concerning the protocol to carry out Reiki, only one study used the self-application of the technique ${ }^{(32)}$. The other employed Reiki sessions with therapists graduated in its several levels and adequately certified. The length of the sessions varied from 10 minutes to one hour and a half. The most common interval between sessions was one week, and the mean number of sessions was six.

Among the studies that made up the final sample, those that used only Reiki as a treatment were a majority $(n=8)^{(31-34,37-40)}$; other treatments used it in conjunction with the use of music $(n=1)^{(35)}$, and the presence of companions $(n=1)^{(36)}$. Chart 1 presents detailed information about the studies selected.

Chart 1 - Characteristics of the studies selected for the integrative review, Recife, Pernambuco, Brazil, 2020

\begin{tabular}{|c|c|c|c|c|c|c|}
\hline \multirow{2}{*}{$\begin{array}{c}\text { Author, year, } \\
\text { country of } \\
\text { origin, database }\end{array}$} & \multirow{2}{*}{$\begin{array}{c}\text { Type of } \\
\text { study, level } \\
\text { of evidence }\end{array}$} & \multirow[b]{2}{*}{ Target population } & \multirow[b]{2}{*}{ Instrument } & \multirow[b]{2}{*}{ Outcome } & \multicolumn{2}{|c|}{ Nursing care strategy } \\
\hline & & & & & Reiki protocol & $\begin{array}{c}\text { Reiki + adjuvant } \\
\text { therapy }\end{array}$ \\
\hline $\begin{array}{l}\text { BESSA et al., } \\
2017^{(34)} \\
\text { Brasil } \\
\text { BVS }\end{array}$ & $\begin{array}{l}\text { Clinical trial } \\
\text { Level II }\end{array}$ & $\begin{array}{l}\text { Adults that sought } \\
\text { therapy regardless } \\
\text { of their clinical } \\
\text { condition }\end{array}$ & Subjective wellbeing scale & $\begin{array}{l}\text { Improvement in the } \\
\text { dimension of positive } \\
\text { affections, with no } \\
\text { influence on the } \\
\text { dimension of negative } \\
\text { affections and on the } \\
\text { satisfaction with the life } \\
\text { of subjective wellbeing }\end{array}$ & $\begin{array}{l}\text { Three sessions of } \\
\text { approximately } 42 \\
\text { minutes each, with } \\
\text { an interval of seven } \\
\text { days between } \\
\text { them. }\end{array}$ & Only Reiki \\
\hline $\begin{array}{l}\text { BREMNER et al., } \\
2016^{(35)} \\
\text { the United } \\
\text { States } \\
\text { BVS }\end{array}$ & $\begin{array}{l}\text { Mixed } \\
\text { methods } \\
\text { Level II }\end{array}$ & Adults with HIV & $\begin{array}{l}\text { Center for Epidemiological } \\
\text { Studies Depression Scale } \\
\text { (CES-D), State Trait Anxiety } \\
\text { Inventory (STAI-Y), Visual } \\
\text { analog scales (VAS) for } \\
\text { pain and anxiety }\end{array}$ & $\begin{array}{l}\text { Diminution of the } \\
\text { scores in the scales } \\
\text { of depression, stress, } \\
\text { anxiety, and pain }\end{array}$ & $\begin{array}{c}\text { Six 30-minute } \\
\text { weekly sessions }\end{array}$ & Reiki and music \\
\hline
\end{tabular}

To be continue 


\begin{tabular}{|c|c|c|c|c|c|c|}
\hline \multirow{2}{*}{$\begin{array}{c}\text { Author, year, } \\
\text { country of } \\
\text { origin, database }\end{array}$} & \multirow{2}{*}{$\begin{array}{l}\text { Type of } \\
\text { study, level } \\
\text { of evidence }\end{array}$} & \multirow[b]{2}{*}{ Target population } & \multirow[b]{2}{*}{ Instrument } & \multirow[b]{2}{*}{ Outcome } & \multicolumn{2}{|c|}{ Nursing care strategy } \\
\hline & & & & & Reiki protocol & $\begin{array}{c}\text { Reiki + adjuvant } \\
\text { therapy }\end{array}$ \\
\hline $\begin{array}{l}\text { ORSAK et al., } \\
2015^{(36)} \\
\text { the United } \\
\text { States } \\
\text { BVS }\end{array}$ & $\begin{array}{l}\text { Clinical trial } \\
\text { Level II }\end{array}$ & $\begin{array}{l}\text { Adults undergoing } \\
\text { chemotherapy }\end{array}$ & $\begin{array}{l}\text { Profile of Mood States } \\
\text { Short Form Questionnaire }\end{array}$ & $\begin{array}{l}\text { Reiki was classified as } \\
\text { relaxing, with no side } \\
\text { effects Reiki and the } \\
\text { companion groups } \\
\text { reported mood } \\
\text { improvements }\end{array}$ & $\begin{array}{l}\text { During each } \\
\text { chemotherapy } \\
\text { session, a 30-minute } \\
\text { Reiki session was } \\
\text { carried out; a } \\
\text { total of four Reiki } \\
\text { sessions were } \\
\text { carried out }\end{array}$ & $\begin{array}{l}\text { Reiki and groups } \\
\text { of companions }\end{array}$ \\
\hline $\begin{array}{l}\text { BIROCCO et al., } \\
2012^{(31)} \\
\text { Italy } \\
\text { BVS }\end{array}$ & $\begin{array}{l}\text { Quasi- } \\
\text { experimental } \\
\text { Study } \\
\text { Level III }\end{array}$ & $\begin{array}{l}\text { Adults undergoing } \\
\text { chemotherapy }\end{array}$ & $\begin{array}{l}\text { Visual analog scales (VAS) } \\
\text { for pain and anxiety }\end{array}$ & $\begin{array}{l}\text { In patients who received } \\
\text { the four Reiki sessions, } \\
\text { there was a statistically } \\
\text { significant diminution } \\
\text { in the mean score of } \\
\text { the Visual Analog Scales } \\
\text { (VAS) for anxiety }\end{array}$ & $\begin{array}{l}\text { Each Reiki session } \\
\text { lasted for about } \\
30 \text { minutes. A } \\
\text { maximum of four } \\
\text { sessions of Reiki } \\
\text { were applied in } \\
\text { four sessions of } \\
\text { chemotherapy }\end{array}$ & Only Reiki \\
\hline $\begin{array}{c}\text { CUNEO et al., } \\
2011^{(32)} \\
\text { the United States } \\
\text { BVS }\end{array}$ & $\begin{array}{l}\text { Quasi- } \\
\text { Experimental } \\
\text { Study } \\
\text { Level III }\end{array}$ & Nurses & $\begin{array}{l}\text { Perceived Stress Scale } \\
\text { (PSS) }\end{array}$ & $\begin{array}{l}\text { Participants who } \\
\text { practiced Reiki with } \\
\text { the most frequency } \\
\text { presented diminished } \\
\text { stress scores, according } \\
\text { to the Perceived Stress } \\
\text { Scale (PSS) }\end{array}$ & $\begin{array}{l}\text { Nurses self-applied } \\
\text { Reiki in sessions } \\
\text { lasting from } 10 \text { to } \\
15 \text { minutes, daily, } \\
\text { for } 21 \text { days }\end{array}$ & Only Reiki \\
\hline $\begin{array}{l}\text { BOWDEN et al., } \\
2011^{(37)} \\
\text { the United } \\
\text { Kingdom } \\
\text { BVS }\end{array}$ & $\begin{array}{l}\text { Clinical trial } \\
\text { Level II }\end{array}$ & University students & $\begin{array}{c}\text { Depression, Anxiety, and } \\
\text { Stress Scale (DASS) and } \\
\text { Hospital Anxiety and } \\
\text { Stress Scale (HADS) }\end{array}$ & $\begin{array}{c}\text { Participants with } \\
\text { strong anxiety and/ } \\
\text { or depression, } \\
\text { who received Reiki } \\
\text { showed a progressive } \\
\text { improvement in general } \\
\text { mood. }\end{array}$ & $\begin{array}{l}\text { Six 30-minute } \\
\text { sessions during a } \\
\text { period from two to } \\
\text { eight weeks }\end{array}$ & Only Reiki \\
\hline $\begin{array}{l}\text { BOWDEN et al., } \\
2010^{(38)} \\
\text { the United } \\
\text { Kingdom } \\
\text { BVS }\end{array}$ & $\begin{array}{l}\text { Clinical trial } \\
\text { Level II }\end{array}$ & University students & $\begin{array}{l}\text { Depression, Anxiety, and } \\
\text { Stress Scale (DASS) }\end{array}$ & $\begin{array}{l}\text { The higher the score } \\
\text { of pre-intervention } \\
\text { stress, the higher the } \\
\text { reduction throughout } \\
\text { the intervention }\end{array}$ & $\begin{array}{l}\text { Ten 20-minute } \\
\text { sessions, during } \\
\text { a period from } 2 \\
\text { weeks and a half to } \\
12 \text { weeks }\end{array}$ & Only Reiki \\
\hline $\begin{array}{l}\text { RICHESON et al., } \\
2010^{(39)} \\
\text { the United } \\
\text { States } \\
\text { Web of Science }\end{array}$ & $\begin{array}{l}\text { Clinical trial } \\
\text { Level II }\end{array}$ & $\begin{array}{l}\text { Elders living in the } \\
\text { community with } \\
\text { medical diagnosis } \\
\text { of pain, depression, } \\
\text { or anxiety }\end{array}$ & $\begin{array}{c}\text { Geriatric Depression } \\
\text { Scale (GDS-15), Hamilton } \\
\text { Anxiety Rating Scale } \\
\text { (HAM-A) }\end{array}$ & $\begin{array}{l}\text { The scores GDS-15 } \\
\text { and HAM-A in the } \\
\text { experimental group had } \\
\text { significant reductions in } \\
\text { depression and anxiety, } \\
\text { when compared to the } \\
\text { control-group }\end{array}$ & $\begin{array}{l}\text { 45-minute Reiki } \\
\text { sessions, once a } \\
\text { week, for eight } \\
\text { weeks }\end{array}$ & Only Reiki \\
\hline $\begin{array}{l}\text { VITALE et al., } \\
2006^{(33)} \\
\text { the United } \\
\text { States } \\
\text { BVS }\end{array}$ & $\begin{array}{l}\text { Quasi- } \\
\text { Experimental } \\
\text { Study } \\
\text { Level III }\end{array}$ & $\begin{array}{l}\text { Adult women } \\
\text { with scheduled } \\
\text { abdominal } \\
\text { hysterectomies }\end{array}$ & $\begin{array}{l}\text { State-Trait Anxiety } \\
\text { Inventory (STAI) }\end{array}$ & $\begin{array}{l}\text { At the moment } \\
\text { of discharge, the } \\
\text { experimental group } \\
\text { presented a lower mean } \\
\text { in the anxiety score than } \\
\text { the control group }\end{array}$ & $\begin{array}{l}\text { A 30-minute Reiki } \\
\text { session: in the same } \\
\text { day surgery was } \\
\text { scheduled and } 24 \\
\text { and } 48 \text { hours after it }\end{array}$ & Only Reiki \\
\hline $\begin{array}{l}\text { SHORE et al., } \\
2004^{(40)} \\
\text { the United States } \\
\text { BVS }\end{array}$ & $\begin{array}{l}\text { Clinical trial } \\
\text { Level II }\end{array}$ & $\begin{array}{l}\text { Adults with } \\
\text { symptoms of stress } \\
\text { and depression }\end{array}$ & $\begin{array}{c}\text { Beck Depression Inventory } \\
\text { (BDI), Beck Hopelessness } \\
\text { Scale (BHS) and Perceived } \\
\text { Stress Scale (PSS) }\end{array}$ & $\begin{array}{l}\text { Participants who received } \\
\text { Reiki showed lower } \\
\text { scores in depression and } \\
\text { stress scales, after the } \\
\text { treatment and also one } \\
\text { year later }\end{array}$ & $\begin{array}{l}\text { Reiki sessions } \\
\text { lasting for one hour } \\
\text { and a half, once a } \\
\text { week, for six weeks }\end{array}$ & Only Reiki \\
\hline
\end{tabular}

\section{DISCUSSION}

From the ten articles analyzed, the United States of America (USA) has the highest number of publications, followed by United Kingdom, Italy, and Brazil. The predominance of NorthAmericans is justified by their growing interest in complementary and alternative medicine (CAM), which encourages researches in this field, especially after the creation of the National Center of Complementary and Alternative Medicine (NCCAM) ${ }^{(41)}$. In
Brazil, although Reiki is part of the list of Complementary and Integrative Practices, integrated to the Single Health System ${ }^{(16)}$ and its wide acceptance in the national setting, there are still few researches about this therapy.

After the articles were reviewed, a great preoccupation can be seen in the scientific community with regard to the criteria adopted by researchers to evaluate the effect/efficacy of the Reiki therapy in the several settings of care in different populations. These weaknesses or methodological biases include: method, 
sample size, sampling criteria, diversified use of evaluation instruments and protocols to apply the Reiki technique $\mathrm{e}^{(24,31,33)}$.

Regarding their methodological approach, all articles used quantitative data to measure the effect of the Reiki therapy. However, six publications added qualitative data in their studies ${ }^{(31-33,35-36,39)}$.

In the scientific field, there is no consensus with regard to the best research method for the analysis of energetic therapies, with some authors questioning the way in which studies measure the efficacy of the laying on of hands, not considering the individual experience of participants, and the use of random analysis models that are the same ones applied to drugs, considered to be the "golden-standard" in medical research (24).

In this review, a study presented, as a limitation, the fact that they did not evaluate the motivation of the participant in seeking the Reiki therapy ${ }^{(34)}$; other researchers suggest qualitative researches or mixed methods to better understand the experience of the Reiki therapy from the perspective of the participants in the research ${ }^{(24,33,35)}$ and its benefits ${ }^{(39)}$. However, other works recommended the use of controlled and randomized studies to confirm the efficacy of this practice ${ }^{(32,37)}$.

Regarding their population, all studies use the Reiki therapy in adults, which can be confirmed in the researches carried out in the databases for this review.

In the works selected, there is an evident diversity of instruments used to evaluate the results, considering wellbeing, quality of life, pain, depression, and anxiety. Despite the reliability and validity of these instruments, the results found presented differences that may be related to the conformance of these instruments to the object of the research, thus leading to a methodological bias ${ }^{(24)}$.

As a result, it can be inferred that, when working with subjective variables such as the ones described above, it is necessary to conceive differently the health/disease processes and the theoretical/technical means to care for people under mental suffering.

The lack of standardization of the protocols used to apply the Reiki intervention was evident in the studies included in this review. This heterogeneity is related to the type, frequency, duration of the practice, and experience level of the professional ${ }^{(42)}$. Two studies used, as a methodological approach, the clinical trial and the methodological rigor during the application of Reiki. However, practitioners used Reiki techniques and symbols intuitively, to attend to the individual needs of each participant ${ }^{(37-38)}$.

The level of experience of the therapist may be a methodological bias, since the effectiveness of the technique of laying on hands may be related to it ${ }^{(24)}$. However, the self-application of Reiki by nurses who have received 21 days of training in the technique was capable of diminishing levels of stress related to work $^{(32)}$.

The diversity in the protocols can be explained by the several teaching methods used by Reiki masters. The complexity in the research of this therapy is evident, with authors that suggest more creative approaches, such as the use of bioelectrography before and after treatment sessions to measure the results of the energetic work ${ }^{(33)}$, as well as individual treatments that consider the subjectivities and needs of the patient ${ }^{(24)}$.

The Reiki therapy, as a strategy of care to the person under psychic suffering, showed benefits in dealing with stress, anxiety, and depression, be it in the occupational context, where it improved the mood of university students with anxiety and/or depression ${ }^{(37-38)}$, be it in the occupational scope, in which nurses that adopted Reiki as a self-care tool showed reduction in the levels of work-related stress ${ }^{(32)}$.

In the case of chronic diseases, with a strong load of mental suffering, related to invasive procedures, the prolonged use of medication, the stigma and the feeling of being finite, the use of the therapy contributes to manage the pain, the stress, as well as anxiety and depression ${ }^{(43-44)}$. A study has shown that the use of Reiki in association to music helped diminishing these disorders in people with $\mathrm{HIV}^{(35)}$.

Furthermore, this technique is considered to be relaxing and has no side effects, offering wellbeing, pain relief, improving in the quality of sleep and diminishing anxiety in patients who undergo chemotherapy ${ }^{(31,36)}$.Therefore, Reiki reestablishes adequate energetic levels for a balance between mind, body, and emotions, and is seen as a non-pharmacological nursing care strategy ${ }^{(45)}$.

According to Watson's nursing theory, the spiritual dimension is part of the transpersonal care model ${ }^{(46)}$. The constructs established by this theoretical milestone reflect the relations between nurse and patient, which are permeated by: presence, personal development, acceptance of the unknown, and trust. This model also states that hope can transform both the nurse and the person cared for. These ideas are reinforced by energetic therapies one of which is Reiki, which seek to give a stronger feeling of spiritual consciousness to the parties involved ${ }^{(47)}$.

The complexity and the subjectivity of the factors involved in the care of people who undergo psychic suffering demand the actions of an interdisciplinary team in many levels of attention, and nurses, as part of said team, can contribute with technical knowledge and abilities inherent to their education, in addition to further therapeutic practices that can be added to daily care, such as Reiki.

In this context, Reiki was found to be a promising tool when inserted in the practice of the interdisciplinary team through professionals introduced and certified in the practice ${ }^{(39)}$. As a result, it can be understood as a therapeutic resource, which is still seldom used by psychiatric nursing, but whose clinical involvement is expanding ${ }^{(33)}$.

Furthermore, through the analysis of scientific evidences about the use of Reiki, it can be understood as an innovative technology of care, which is of low cost and can be used by nurses and other professionals that promote mental health, with previous training, in situations of mental suffering. This is because the energy that flows through the hands of the practitioner can harmonize the individual according to their needs and, as a result, can promote physical, mental, and emotional balance, improving their quality of life.

\section{Study limitations}

The limitations of this study include the small number of studies found in the searches in databases. This may be due to the number of databases chosen for the research, their language, and the exclusion of gray literature. As an attempt to reduce the effect of this limitation, the search strategy used broad terms and did not restrict studies with regard to the year of publication, seeking to reach a higher number of results. However, the scarcity of works on the theme may also be attributed to the fact that these complementary and integrative practices to mental health care are a novelty. 


\section{Contributions to the fields of Nursing, Health or Public Policy}

This research can contribute to give substance to proposals of action in mental health care in the field of Nursing, through the publication and summary of scientific evidences for the use of complementary and integrative practices, among which Reiki. Thus, it can empower nurses and multiprofessional teams; seek holistic and humane attention; and attend to the uniqueness of people under mental suffering, in accordance to the prescriptions of the Brazilian Psychiatric Reform.

Consequently, the collection, analysis, and integration of the findings within a global meaning may encourage the creation of Unique Therapeutic Projects and the development of new researches that involve nursing care and multidisciplinary teams, based on non-pharmacological strategies to treat mental disorders in the multiple settings of health care.

\section{CONCLUSIONS}

Through the results of the articles analyzed, this study shows that Reiki, as a practice applied to the relief of pain and psychic suffering by nurses or by other members of the multidisciplinary team of health care contributes for the improvement of quality standards in assistance, since it humanizes the care provided.

It was noteworthy that scientific evidences are still scarce in the databases analyzed with regard to the use of Reiki for people in mental suffering, but their number is growing. Therefore, future researches must be carried out to enhance the production of knowledge about this technique, as an instrument of care in mental health.

Additionally, the results have shown that the use of the Reiki therapy presented benefits for people under psychic suffering, such as reducing stress, anxiety, depression symptoms, and physical pain. Both in isolation and when together with another type of treatment, this therapy has also been used for relaxation, aiding in the improvement of quality of life.

However, questions have been raised with regard to the scientific evidences found about the methodologies used to evaluate the efficacy of energetic therapies. Some authors recommended qualitative or mixed-method evaluative studies, believing that quantitative researches do not reveal subtle changes in vibration.

\section{REFERENCES}

1. Orešković S. Breaking down the Silo Mentality in Global Mental Health: the new role for the schools of Public Health. Psychiatr Danub [Internet]. 2016[cited 2019 Oct 20];28(4):318-20. Available from: http://www.ncbi.nlm.nih.gov/pubmed/27855420

2. Kohn R, Ali AA, Puac-Polanco V, Figueroa C, López-Soto V, Morgan K, et al. Mental health in the Americas: an overview of the treatment gap. Rev Panam Salud Pública [Internet]. 2018 [cited 2019 Oct 20];42:e165. Available from: http://iris.paho.org/xmlui/handle/123456789/49540

3. Barroso AGC, Abreu LM de, Bezerra MAA, Ibiapina SLD, Brito HB de. Mental disorders: the meaning for relatives. Rev Bras Promoç Saúde [Internet]. 2004 [cited 2019 Oct 20];17(03):99-108. Available from: https://periodicos.unifor.br/RBPS/article/download/686/2054

4. Ministério da Saúde (SP). Secretaria de Atenção à Saúde. Política Nacional de Humanização - PNH [Internet]. Brasília: Ministério da Saúde; 2013 [cited 2019 Oct 20]. Available from: https://bvsms.saude.gov.br/bvs/publicacoes/politica_nacional_humanizacao_pnh_folheto.pdf

5. World Health Organization. The global burden of disease: 2004 update [Internet]. World Health Organization; 2008 [cited 2019 Oct 20 ]. Available from: https://www.who.int/healthinfo/global_burden_disease/GBD_report_2004update_full.pdf?ua=1

6. Santos ÉG, Siqueira MM de. Prevalence of mental disorders in the Brazilian adult population: a systematic review from 1997 to 2009. J Bras Psiquiatr. 2010;59(3):238-46. https://doi.org/10.1590/S0047-20852010000300011

7. Organización Panamericana de la Salud. La carga de los trastornos mentales en la Región de las Américas [Internet]. Washington, D.C.: OPS; 2018 [cited 2019 Oct 20]. Available from: http://www.codajic.org/sites/www.codajic.org/files/Carga de los trastornos mentales en la Región de las Américas 2018.pdf

8. World Health Organization. Mental health action plan 2013-2020 [Internet]. Geneva: World Health Organization; 2013 [cited 2019 Oct 20 ]. Available from: https://apps.who.int/iris/bitstream/handle/10665/89966/9789241506021_eng.pdf

9. Moreira FP, Jansen K, Cardoso TA, Mondin TC, Magalhães PV, Kapczinski F, et al. Metabolic syndrome and psychiatric disorders: a populationbased study. Brazilian J Psychiatry. 2019;41(1):38-43. https://doi.org/10.1590/1516-4446-2017-2328

10. Niedzwiedz CL, Knifton L, Robb KA, Katikireddi SV, Smith DJ. Depression and anxiety among people living with and beyond cancer: a growing clinical and research priority. BMC Cancer [Internet]. 2019 [cited 2019 Oct 20];19(1):943. Available from: https://bmccancer. biomedcentral.com/articles/10.1186/s12885-019-6181-4

11. Remien RH, Stirratt MJ, Nguyen N, Robbins RN, Pala AN, Mellins CA. Mental health and HIV/AIDS. AIDS [Internet]. 2019[cited 2019 Oct 29];33(9):1411-20. Available from: http://journals.Iww.com/00002030-201907150-00001

12. De Sordi LP, Bigatto KRS, Santos SG, Machado AL. Comorbidities in users of a mental health service. Rev Port Enferm Saúde Ment [Internet]. 2015 [cited 2019 Oct 20];(SPE2):89-94. Available from: http://www.scielo.mec.pt/pdf/rpesm/nspe2/nspe2a15.pdf

13. Alcântara CB, Capistrano FC, Czarnobay J, Ferreira ACZ, Brusamarello T, Maftum MA. Drug therapy for people with mental disorders in the view of nursing professionals. Esc Anna Nery. 2018;22(2). https://doi.org/10.1590/2177-9465-ean-2017-0294

14. Ministério da Saúde (BR). Secretaria de Atenção à Saúde, Departamento de Atenção Básica. Política nacional de práticas integrativas e complementares no SUS: atitude de ampliação de acesso [Internet]. 2ed. Brasília: Ministério da Saúde; 2015[cited 2019 Oct 20]. 96 p. Available from: https://bvsms.saude.gov.br/bvs/publicacoes/politica_nacional_praticas_integrativas_complementares_2ed.pdf 
Reiki as nursing care to people in mental suffering: an integrative review Santos CMR, Crispim MO, Silva TTM, Souza RCR, Frazão CMFQ, Frazão IS

15. Aguiar J, Kanan LA, Masiero AV. Integrative and Complementary Practices in basic health care: a bibliometric study of Brazilian production. Saúde Debate. 2019;43(123):1205-18. https://doi.org/10.1590/0103-1104201912318

16. Ministério da Saúde (BR). Glossário temático : práticas integrativas e complementares em saúde [Internet]. Brasília - DF: Ministério da Saúde; 2018 [cited 2019 Oct 20]. Available from: http://189.28.128.100/dab/docs/portaldab/publicacoes/glossario_pics.pdf

17. Erdogan Z, Cinar S. The effect of Reiki on depression in elderly people living in nursing home. Indian J Tradit Knowl [Internet]. 2016 [cited 2019 Oct 20];15(1):35-40. Available from: http://nopr.niscair.res.in/handle/123456789/33556

18. Bukowski EL. The use of self-Reiki for stress reduction and relaxation. J Integr Med [Internet]. 2015 [cited 2019 Oct 20];13(5):336-40. Available from: https://linkinghub.elsevier.com/retrieve/pii/S209549641560190X

19. Rosada RM, Rubik B, Mainguy B, Plummer J, Mehl-Madrona L. Reiki Reduces Burnout Among Community Mental Health Clinicians. J Altern Complement Med. 2015;21(8):489-95. https://doi.org/10.1089/acm.2014.0403

20. Spezzia S, Spezzia S. The use of reiki in Health Care and the in the Unified Health System. Rev Saúde Pública [Internet]. 2018 [cited 2019 Oct 20];1(1):108-15. Available from: http://revista.escoladesaude.pr.gov.br/index.php/rspp/article/view/49

21. Freitag VL, Andrade A, Badke MR, Heck RM, Milbrath VM. Reiki therapy in Family Health Strategy: perceptions of nurses. Rev Pesqui: Cuid Fundam [Internet]. 2018[cited 2019 Oct 20];10(1):248. Available from: http://seer.unirio.br/index.php/cuidadofundamental/article/ view/5967

22. Mendes DS, Moraes FS, Lima GO, Silva PR, Cunha TA, Crossetti MGO, et al. Benefits of integrative and complementary practices in nursing care. J Health NPEPS [Internet]. 2019 [cited 2019 Oct 20];4(1):302-18. Available from: https://periodicos.unemat.br/index.php/jhnpeps/ article/view/3452

23. Conselho Federal de Enfermagem (COFEN). Resolução COFEN No 581/2018. Atualiza, no âmbito do Sistema Cofen/Conselhos Regionais de Enfermagem, os procedimentos para Registro de Títulos de Pós-Graduação Lato e Strictu Sensu concedido a Enfermeiros e aprova a lista das especialidades [Internet]. Brasília - DF: COFEN; 2018[cited 2019 Oct 20]. Available from: http://www.cofen.gov.br/wp-content/ uploads/2018/07/RESOLU\%C3\%87\%C3\%83O-COFEN-N\%C2\%BA-0581-2018.pdf

24. Motta PMR, Barros NF. The application of the technique of imposition of hands on stress-anxiety: a systematic literature review. Cad Ter Ocup UFSCar [Internet]. 2015 [cited 2019 Oct 20];23(2):381-92. Available from: http://doi.editoracubo.com.br/10.4322/0104-4931.ctoAR0534

25. Joyce J, Herbison GP. Reiki for depression and anxiety. Cochrane Database Syst Rev [Internet]. 2015 [cited 2019 Oct 20];(4). Available from: http://doi.wiley.com/10.1002/14651858.CD006833.pub2

26. Whittemore R, Knafl K. The integrative review: updated methodology. J Adv Nurs. 2005;52(5):546-53. https://doi. org/10.1111/j.1365-2648.2005.03621.x

27. Santos CMC, Pimenta CAM, Nobre MRC. The PICO strategy for the research question construction and evidence search. Rev Latino-Am Enfermagem. 2007;15(3):508-11. https://doi.org/10.1590/S0104-11692007000300023

28. Moher D, Liberati A, Tetzlaff J, Altman DG. Preferred reporting items for systematic reviews and meta-analyses: The PRISMA Statement. PLoS Med. 2009;6(7):e1000097. https://doi.org/10.1371/journal.pmed.1000097

29. Ursi ES, Gavão CM. Perioperative prevention of skin injury: an integrative literature review. Rev Latino-Am Enfermagem. 2006;14(1):124-31. https://doi.org/10.1590/S0104-11692006000100017

30. Fineout-Overholt E, Melnyk BM, Stillwell SB, Williamson KM. Evidence-Based Practice Step by Step: critical appraisal of the evidence: Part I. Am J Nurs. 2010;110(7):47-52. https://doi.org/10.1097/01.NAJ.0000383935.22721.9c

31. Birocco N, Guillame C, Storto S, Ritorto G, Catino C, Gir N, et al. The effects of Reiki therapy on pain and anxiety in patients attending a day oncology and infusion services Unit. Am J Hosp Palliat Med [Internet]. 2012 [cited 2019 Oct 20];29(4):290-4. Available from: http://journals. sagepub.com/doi/10.1177/1049909111420859

32. Cuneo CL, Curtis Cooper MR, Drew CS, Naoum-Heffernan C, Sherman T, Walz K, et al. The effect of Reiki on work-related stress of the registered nurse. J Holist Nurs [Internet]. 2011 [cited 2020 Jan 28];29(1):33-43. Available from: http://journals.sagepub.com/ doi/10.1177/0898010110377294

33. Vitale AT, O'Connor PC. The effect of Reiki on pain and anxiety in women with abdominal hysterectomies: a quasi-experimental pilot study. Holist Nurs Pract [Internet]. 2006 [cited 2020 Jan 28];20(6):263-72;quiz 273-4. Available from: http://www.ncbi.nlm.nih.gov/ pubmed/17099413

34. Bessa JHN, Jomar RT, Silva AV, Peres EM, Wolter RMCP, Oliveira DC. Reiki effect on subjective well-being: experimental study. Enferm Glob [Internet]. 2017[cited 2019 Oct 20];16(4):408. Available from: http://revistas.um.es/eglobal/article/view/259141

35. Bremner MN, Blake BJ, Wagner VD, Pearcey SM. Effects of Reiki with music compared to music only among people living with HIV. J Assoc Nurses AIDS Care. 2016;27(5):635-47. https://doi.org10.1016/j.jana.2016.04.004

36. Orsak G, Stevens AM, Brufsky A, Kajumba M, Dougall AL. The effects of Reiki Therapy and companionship on quality of life, mood, and symptom distress during chemotherapy. J Evid Based Complement Altern Med [Internet]. 2015 [cited 2019 Oct 20];20(1):20-7. Available from: http://journals.sagepub.com/doi/10.1177/2156587214556313

37. Bowden D, Goddard L, Gruzelier J. A Randomised controlled single-blind trial of the efficacy of Reiki at benefitting mood and well-being. Evidence-Based Complement Alt Med [Internet]. 2011 [cited 2019 Oct 20];2011:1-8. Available from: http://www.hindawi.com/journals/ ecam/2011/381862/ 
38. Bowden D, Goddard L, Gruzelier J. A randomised controlled single-blind trial of the effects of Reiki and positive imagery on well-being and salivary cortisol. Brain Res Bull. 2010;81(1):66-72. https://doi.org10.1016/j.brainresbull.2009.10.002

39. Richeson NE, Spross JA, Lutz K, Peng C. Effects of Reiki on anxiety, depression, pain, and physiological factors in community-dwelling older adults. Res Gerontol Nurs [Internet]. 2010[cited 2020 Jan 20];3(3):187-99. Available from: http://www.slackinc.com/doi/resolver.asp?d oi $=10.3928 / 19404921-20100601-01$

40. Shore AG. Long-term effects of energetic healing on symptoms of psychological depression and self-perceived stress. Alt Ther Health Med [Internet]. 2004 [cited 2019 Oct 20];10(3):42-8. Available from: https://pesquisa.bvsalud.org/portal/resource/pt/mdl-15154152

41. National Institutes of Health (NIH). National Center for Complementary and Integrative Health. Important Events in NCCIH History [Internet]. The NIH Almanac. 2020 [cited 2020 Jan 20]. Available from: https://www.nih.gov/about-nih/what-we-do/nih-almanac/ national-center-complementary-integrative-health-nccih\#events

42. Baldwin AL, Vitale A, Brownell E, Scicinski J, Kearns M, Rand W. The Touchstone Process: an ongoing critical evaluation of Reiki in the scientific literature. Holist Nurs Pract [Internet]. 2010 [cited 2019 Oct 20];24(5):260-76. Available from: http://journals.Iww. com/00004650-201009000-00005

43. Batista KM, Borges LM. Reiki therapy as an intervention strategy for pain and stress in nursing students. Rev Divulg Científ Sena Aires [Internet]. 2020[cited 2020 Sep 20];9(1):109-17. Available from: http://revistafacesa.senaaires.com.br/index.php/revisa/article/view/481

44. Beulke SL, Vanucci L, Salles LF, Turrini RNT. Reiki in the relief of chemotherapy-related biopsychoemotional signs and symptoms. Cogitare Enferm [Internet]. 2019[cited 2019 Oct 20];24:e56694. Available from: https://revistas.ufpr.br/cogitare/article/view/56694

45. Freitag VL, Andrade A, Badke MR. The Reiki as therapeutic form in health care: a narrative literature review. Enferm Glob [Internet]. 2015[cited 2019 Oct 20];14(2):335. Available from: http://revistas.um.es/eglobal/article/view/200511

46. Natale GW. Reconnecting to Nursing Through Reiki. Creat Nurs [Internet]. 2010[cited 2019 Oct 20];16(4):171-6. Available from: http:// connect.springerpub.com/lookup/doi/10.1891/1078-4535.16.4.171

47. Watson J. Enfermagem pós-moderna e futura: um novo paradigma da enfermagem. Loures: Ed. Técnicas e Científicas; 2002.324 p. 